\title{
On the Effects of Urea and Water Injection on Particles Across the SCR Catalyst in a Heavy - Duty Euro VI Diesel Engine
}

\author{
Prasath K., Arun ; Bernemyr , Hanna ; Erlandsson, Anders
}

Published in:

S A E Technical Papers

Link to article, DOI:

$10.4271 / 2020-01-2196$

Publication date:

2020

Document Version

Publisher's PDF, also known as Version of record

Link back to DTU Orbit

Citation (APA):

Prasath K., A., Bernemyr, H., \& Erlandsson, A. (2020). On the Effects of Urea and Water Injection on Particles Across the SCR Catalyst in a Heavy - Duty Euro VI Diesel Engine. S A E Technical Papers, [2020-01-2196]. https://doi.org/10.4271/2020-01-2196

\section{General rights}

Copyright and moral rights for the publications made accessible in the public portal are retained by the authors and/or other copyright owners and it is a condition of accessing publications that users recognise and abide by the legal requirements associated with these rights.

- Users may download and print one copy of any publication from the public portal for the purpose of private study or research.

- You may not further distribute the material or use it for any profit-making activity or commercial gain

- You may freely distribute the URL identifying the publication in the public portal 


\title{
On the Effects of Urea and Water Injection on Particles across the SCR Catalyst in a Heavy - Duty Euro VI Diesel Engine
}

\author{
Arun Prasath K and Hanna Bernemyr KTH Royal Institute of Technology
}

Anders Erlandsson KTH Royal Institute of Technology / DTU

Citation: K, A. P., Bernemyr, H., and Erlandsson, A., "On the Effects of Urea and Water Injection on Particles across the SCR Catalyst in a Heavy - Duty Euro VI Diesel Engine," SAE Technical Paper 2020-01-2196, 2020, doi:10.4271/2020-01-2196.

\section{Abstract}

$\longrightarrow$ article emissions from heavy-duty engines are regulated both by mass and number by Euro VI regulation. Understanding the evolution of particle size and number from the exhaust valve to the tail pipe is of vital importance to expand the possibilities of particle reduction. In this study, experiments were carried out on a heavy-duty Euro VI engine after-treatment system consisting of diesel oxidation catalyst, diesel particulate filter and selective catalytic reduction (SCR) unit with AdBlue injection followed by ammonia slip catalyst. The present work focusses on the SCR unit with regard to total particle number with and without nucleation particles both. Experiments were conducted by varying the AdBlue injection quantity, SCR inlet temperature [to vary the reaction temperature], exhaust mass flow rate [to vary the residence time in SCR], and fuel injection pressures [to vary inlet particle number and inlet $\mathrm{NO}_{\mathrm{x}}$ ]. Sampling for particle measurements was performed at the inlet, upstream of the urea injector and the outlet of the SCR. Particle measurements were made using two different twostage dilution systems, for measuring non-volatile and volatile particles, respectively. The total particle number (PN) was measured using two different condensation particle counters (CPC), one with the cut-off size at $23 \mathrm{~nm}$ and another with a cut-off size at $7 \mathrm{~nm}$ to capture nuclei mode particles. An increase in the total number of particles was observed at $400^{\circ} \mathrm{C}$ and 1200 bar of fuel injection pressure with the higher AdBlue injection quantities compared to the dry-run SCR. At $400^{\circ} \mathrm{C}$, a surge in nucleation occurs irrespective of the fuel injection pressures. An experiment was also made to isolate the water droplets effect on PN from nitrate formation. The SCR was injected with de-ionized water and a PN reduction was observed across the SCR and the reduction was higher with higher inlet PN to the SCR.

\section{Introduction}

$\int \mathrm{rat}$ article emissions are a concern in regard to air quality. Various studies $[1, \underline{2}]$ have reported that particle emissions are affecting health. Internal combustion engine (ICE) is one of the primary emission sources for particles. Hence legislations have been laid on restricting particle emissions from ICEs. From Euro VI legislation for heavy-duty (HD) applications, regulation is in place for the total Particle Number (PN) emitted. For regulatory measurements, Particle Number (PN) emissions are measured using instruments complying with Particle Measurement Programme (PMP) requirements []] .

Particles emitted from diesel engines HD diesel engines is of interest in this work. Particles emitted by diesel engines are chain-like aggregates, consisting of primary particles with each particle aggregate containing many agglomerates and further connected to each other [4]. The particle size is larger if the agglomerates connected to the primary particles are more in number. Based on the size, particles can be classified into three groups viz.: nuclei mode $(3-30 \mathrm{~nm})$, accumulation mode $(30-500 \mathrm{~nm})$ and coarse mode $(>1 \mu \mathrm{m})$ particles [ $\underline{5}$.
Formation of the particle core takes place during the combustion process in the engine giving rise to the primary particles which are in the nucleation mode, and the tail pipe emission of the particles depends on the type of the exhaust after-treatment system [6]. Each of the exhaust after-treatment devices handle selective emissions such as $\mathrm{HC}, \mathrm{CO}, \mathrm{NO}_{\mathrm{x}}$ and particle emissions. The effect of each exhaust after-treatment device from the perspective of particle emissions could be of interest, as it improves the understanding of particle evolution along the exhaust system.

The exhaust after-treatment system for a Euro VI engine consists of several devices namely diesel oxidation catalyst (DOC), diesel particulate filter (DPF) and selective catalytic reduction (SCR) unit. The present work focusses on the effect of SCR on PN emissions. There have been work on the effect of SCR on PN emissions reported in the literature as follows.

Thiruvengadam et al. [7] have noticed that when the exhaust entering the SCR had a temperature above $380^{\circ} \mathrm{C}$, the urea-injected in SCR gives rise to nucleation mode particles $(6-15 \mathrm{~nm})$ both in steady-state and transient cases while no 
increase was seen at lower exhaust temperature operation points. The experimental study was conducted on a turbocharged heavy-duty Euro IV diesel engine. The after-treatment system contained DOC+DPF+SCR+Ammonia Slip Catalyst (ASC).

Pietikäinen et al. []] have tested the effect of a stand-alone SCR unit on the particle emissions on a four-stroke non-road diesel engine. The effect of load (100\%, 75\%, 50\%, and 25\%) at constant speed $(1500 \mathrm{rpm})$ was evaluated following ISO 8178 E2 cycle. From the results it was observed that on the whole, there was a reduction in PN for about 30\% with the SCR. On the other hand, an increase in PN was observed among the nucleation particles. The portion of the emitted particles that were in the nucleation mode range $(<50 \mathrm{~nm})$ increased from $35 \%$ to $47 \%$. The study [ $\underline{8}$ ] discusses the effect of SCR in standalone operation and there might be influence of higher particle concentration as the experiment was without a DPF. The presence of a DPF could be closer to real world effect of SCR.

In another experimental study by Karjalainen et al. [9]], a heavy-duty diesel off-road engine was tested for the effect of DOC+SCR unit on particle emissions in a transient cold-start cycle. Throughout the cycle the exhaust temperature entering the SCR was less than $250^{\circ} \mathrm{C}$. It was noticed that the total PN reduction with non-volatiles across DOC+SCR was $50.8 \%$ and while the reduction across the DOC was $17.7 \%$ showing a decrease of about 33\% in total non-volatile PN across the SCR. Simultaneously, the total PN reduction with volatiles across DOC + SCR was $95.7 \%$ and across the DOC it was $82.5 \%$ showing a decrease of $13.5 \%$ in total volatile $\mathrm{PN}$ across the SCR. In summary, the test was a transient cold-start cycle showing an effective $\mathrm{PN}$ reduction with SCR inlet temperatures up to $250^{\circ} \mathrm{C}$.

Lee et al. [10] have tested the effect of SCR on a heavy-duty diesel engine with DOC+DPF+SCR+ASC as the exhaust aftertreatment system. The test was performed in 13- mode (ESC) cycle. It was noted that the $\mathrm{NO}_{\mathrm{x}}$ conversion efficiency with and without ASC was $80 \%$ and $53 \%$ respectively. The less $\mathrm{NO}_{\mathrm{x}}$ conversion efficiency without ASC was due to the slip of $\mathrm{NH}_{3}$. $\mathrm{PN}$ was measured using a two-stage dilution system with an evaporation tube to remove the volatiles. It was noted that the evaporation tube temperature did not affect the $\mathrm{PN}$ which was attributed to the removal of volatile particles. An increase in PN of about $161 \%$ (in comparison to without and with urea injection) was noted at a 1:1 molar ratio of $\mathrm{NH}_{3} / \mathrm{NO}_{\mathrm{x}}$. Furthermore, from Scanning Electron Microscope (SEM) images, grains of spherical unreacted urea particles $(200 \mathrm{~nm}-1 \mu \mathrm{m})$ were observed at an SCR inlet temperature of $250^{\circ} \mathrm{C}$. The PN increase across the SCR is of very high percentage value (161\%) this may be due to high filtration efficiency of the DPF. Hence absolute change in PN across the SCR is of interest in the place of relative change. In addition to that, the possibility of influence of the sample conditioning on PN measurements can be ruled out by comparing two different sample dilution conditioning methods.

Amanatidis et al. [11] made an experimental study on a turbocharged light-duty (LD) Euro 4 diesel engine for the effect of SCR on particle emissions. The after-treatment system contained DPF+SCR without DOC and ASC. Experiments were performed at constant speed with two different loads to analyze the effect of excess $\mathrm{NH}_{3}$ levels at the SCR. For this purpose, liquid $\mathrm{NH}_{3}$ was injected in excess before the SCR instead of the urea-water solution (AdBlue) such that the concentration of $\mathrm{NH}_{3}$ was $100 \mathrm{ppm}$ after the SCR. The exhaust temperature at the inlet of SCR was $300^{\circ} \mathrm{C}$ (low load) and $400^{\circ} \mathrm{C}$ (high load) respectively. Increase in non-volatile particles $26-136 \%(<23 \mathrm{~nm})$ and $80-193 \%(>23 \mathrm{~nm})$ was observed over the SCR. It was noted that ammonium nitrate, ammonium sulphate as well as ammonium chloride particles were formed in the SCR. The experimental study[11] measured the effect of inlet temperature with liquid $\mathrm{NH}_{3}$ injection before the SCR instead of the urea-water solution. The same experiment in a $\mathrm{HD}$ engine of a commercial truck with urea-water injected SCR will be close to real application. Also different inlet $\mathrm{NO}_{\mathrm{x}}$ values to the SCR is needed to be investigated.

In literature as described above, most studies were conducted in transient and stationary cycle operation of the engine. An analysis at steady state operating conditions of the engine would show more light on the PN change across the SCR. The effect of the mass flow rate through the SCR was not reported in literature and hence it was of interest to be analysed. Also, literature reports higher PN emissions at higher temperatures (above $380^{\circ} \mathrm{C}$ ) [7]. So, an analysis on the low and high temperature of the SCR for the comparison of the temperature could be of interest. These higher temperatures at the SCR is mostly observed in HD Engines. Thus the present work was framed to study the effect of the SCR on PN emissions with various SCR inlet conditions using a HD Euro VI engine. In addition, effect of the dilution systems used for measuring PN may influence the measurement. Thus, a comparison between two different sample dilution conditioning methods could rule out the effect of the dilution systems used for measuring $\mathrm{PN}$ across the SCR. Hence, one dilution system in compliance with PMP regulation (as a reference) and other dilution system with different principle of dilution were the candidates for comparison. Furthermore, the change in PN with AdBlue injection was compared with deionized water injection to isolate the effect of urea and deionized water as these are the constituents in AdBlue solution. Increase in AdBlue injection quantity and its effect on the PN increase was analyzed with different inlet conditions to the SCR.

The hypotheses were framed with the SCR as a system of interest and are expressed as follows.

- Higher urea injection quantities to the SCR increase the salt formation as the concentration of ammonia increases.

- Higher temperatures at the SCR inlet due to higher engine loads will aid the reaction for salt formation due to high reaction temperatures leading to higher PN.

- Higher mass flow rates through the SCR may result in lesser residence time and may result in lesser number of particle emissions as the space velocity of the exhaust is higher.

- Higher fuel injection leads to higher $\mathrm{NO}_{\mathrm{x}}$ and lesser PN from the engine. So higher SCR inlet $\mathrm{NO}_{\mathrm{x}}$ concentration may favour the salt formation in turn leading to higher increase in PN across the SCR.

- With deionized water the $\mathrm{NO}_{\mathrm{x}}$ reduction will be unchanged and thus there may not be particle 
increase across the SCR. On the other hand there could be $\mathrm{PN}$ reduction as the water droplets dry up after sticking many particles.

\section{Objectives}

The objective of this work is to evaluate the effect of various inlet conditions on the particle number concentration and size distribution in a selective catalytic reduction (SCR) unit of a Euro VI HD diesel engine in steady state operation. The parameters swept in the experiment were (i) urea injection quantity (ii) the temperature at the SCR inlet, (iii) the exhaust mass flow rate and (iv) the particle number concentration/ $\mathrm{NO}_{\mathrm{x}}$ at the SCR inlet.

\section{Experimental Setup}

The experiments were performed in a 6-cylinder Euro VI HD Diesel engine with a constant geometry turbocharger. The specifications of the engine are shown in Table 1 . The exhaust treatment systems of the engine were DOC, DPF, SCR and ASC unit. An electrical dynamometer was used to load the engine. The engine was run on commercially available Swedish low sulphur S10 diesel.

\section{Sampling}

The measurements were taken at pre SCR and post ASC as shown in Figure 1, noted as inlet (1) and outlet (2). The measurements made were total $\mathrm{PN}, \mathrm{NO}_{\mathrm{x}}$ and temperature.

TABLE 1 Specifications of the engine

\begin{tabular}{|l|l|}
\hline Engine & Scania D13 \\
\hline Bore & $130 \mathrm{~mm}$ \\
\hline Stroke & $160 \mathrm{~mm}$ \\
\hline Connecting Rod & $255 \mathrm{~mm}$ \\
\hline Compression ratio & $18: 1$ \\
\hline Number of Cylinders & 6 (In-line) \\
\hline After Treatment system & DOC+DPF+SCR+ASC \\
\hline
\end{tabular}

Particle measuring probe used was of multi-hole type [12]. The inlet and outlet sampling lines to the (SCR+ASC) unit were connected to a switching valve made from two temperature resistant ball valves so that the sample flow is not disturbed. The outlets of the valves were combined into a single line to connect to the sample inlet of the instrument. The total length of the sampling line (stainless steel) used from the point of measurement to the primary diluter was $2.3 \mathrm{~m}$. The residence time from the point of measurement to the primary dilution was $0.78 \mathrm{~s}$ which is within the limits $(\leq 3 \mathrm{~s})$ of PMP [12]. The sampling conditions and length of the transfer line were kept the same at location 1 and 2.

$\mathrm{NO}_{\mathrm{x}}$ measurements were taken at locations 1 and 2 using the engine $\mathrm{NO}_{\mathrm{x}}$ sensor at $1 \mathrm{~Hz}$ data logging frequency for 120 seconds. Yttrium-stabilized Zirconia based electrochemical NOx sensor with the measurement range of 0-3000 ppm and with an accuracy of $15-20 \%$ of real value was used. The sensor have no cross sensitivities (e.g. to $\mathrm{CO}, \mathrm{HC}, \mathrm{O}_{2}, \mathrm{CO}_{2}$ or $\mathrm{H}_{2} \mathrm{O}$ ) but the sensor is cross sensitive to NH3. As the inlet measurement was made before the AdBlue injection and outlet measurement was made after the ASC, the error due to ammonia is minimised. Temperature measurements were also made at locations 1 and 2 .

\section{Particle Measurement System}

The total particle number emissions were measured using two different dilution systems. One is a two-stage PMP compliant dilution system (DS1) with an evaporation tube and the other is a two-stage ejector dilution system (DS2). The schematic of the particle measurement system is shown in the overall experimental setup in Figure 2.

DS1 is a two-stage dilution system with an evaporation tube maintained at $350^{\circ} \mathrm{C}$ to measure non-volatile particles. The Primary diluter is a rotating disk type diluter and the secondary diluter is a porous type diluter. Primary dilution is a heated dilution at $150^{\circ} \mathrm{C}$ and secondary dilution is a cooling dilution. A $1.5 \mathrm{~m}$ heated hose maintained at $150^{\circ} \mathrm{C}$ was used after the primary diluter.

DS2 is a two-stage dilution system where the primary and the secondary diluter both are of ejector type. Primary dilution is a heated dilution at $350^{\circ} \mathrm{C}$ to measure non-volatile particles and secondary dilution is a cooling dilution. A $1.5 \mathrm{~m}$ heated hose maintained at $150^{\circ} \mathrm{C}$ was used at the inlet of the primary diluter.

FIGURE 1 Overall schematic diagram of the experimental setup

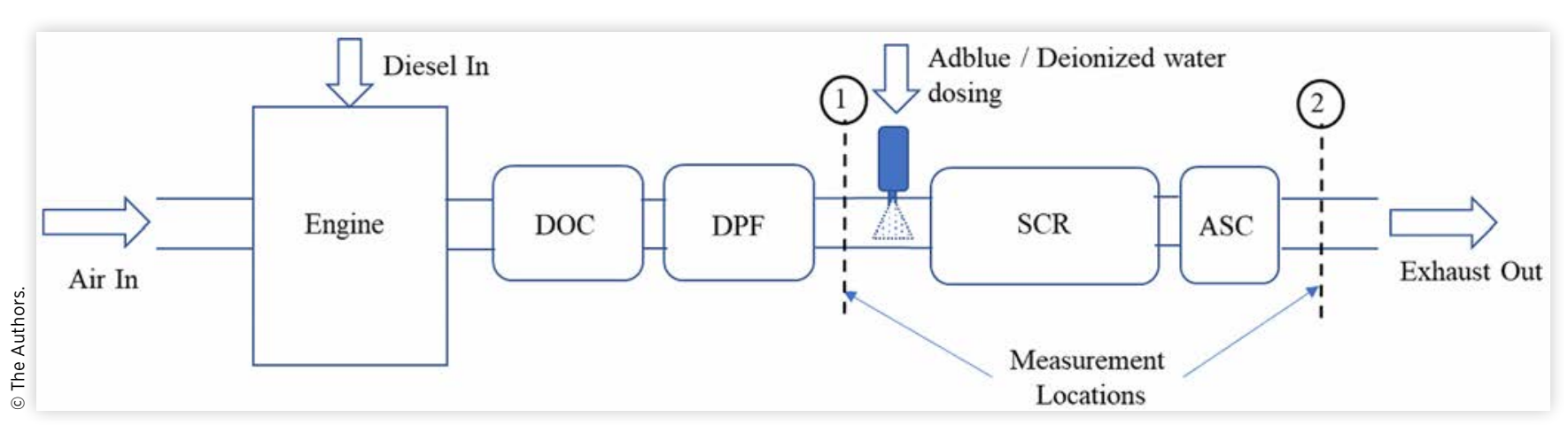




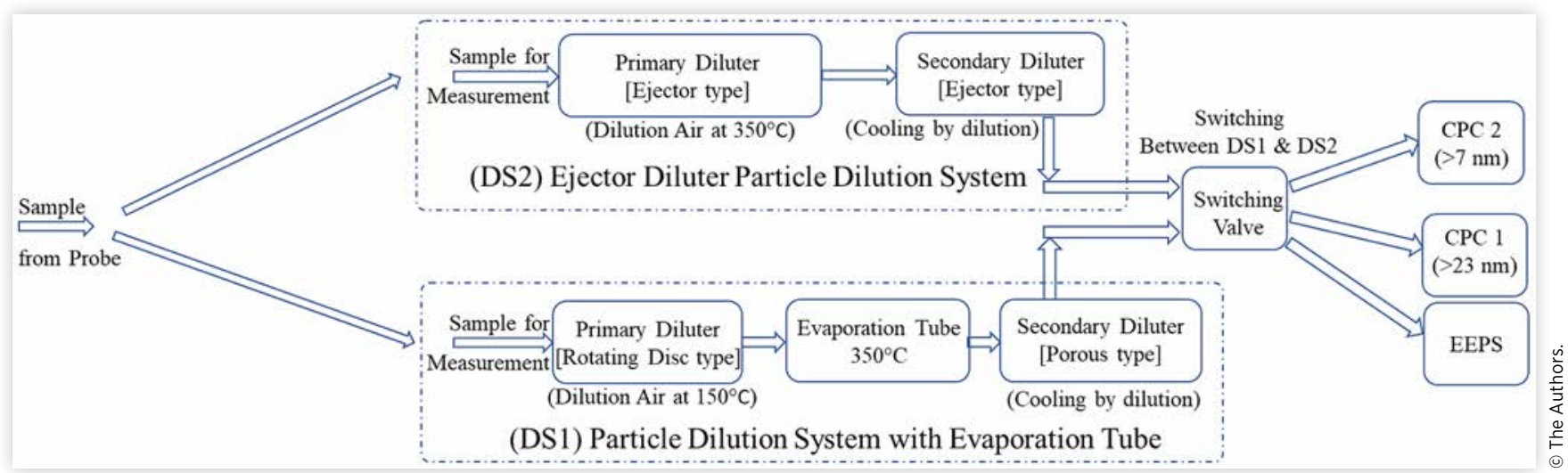

The primary dilution factor was 10 and secondary dilution factor was 15 for both the dilution systems. The outlet of both the instruments was connected to two condensation particle counters (CPC) with a switching valve. First CPC (CPC1) has a cut-off size of $23 \mathrm{~nm}$. This is to measure the total $\mathrm{PN}$ from accumulation mode particles and further larger particles. The second CPC (CPC2) has a cut-off size of $7 \mathrm{~nm}$. This is to measure the total PN from nucleation mode particles and further larger particles. All the particle number measurements reported with both the CPCs were corrected for dilution factors.

For each engine operating point, measurements were taken for three sampling periods to ensure repeatability. While measuring with the CPCs, each sampling period was 120 seconds, at $1 \mathrm{~Hz}$ measurement and data logging frequency.

The particle size distribution was measured using the EEPS (Engine Exhaust Particle Sizer Spectrometer). The size distribution measured by the EEPS is in the range of $5.6 \mathrm{~nm}$ to $560 \mathrm{~nm}$. The excess output from the dilution system DS1 was used as the conditioned sample inlet for EEPS. EEPS measurement was made without the dilution factor correction. As dilution factor is constant throughout the experiments, it affects the distribution only by a constant multiplication value. In the case of the particle size distribution measurement, each trial was 120 seconds at $10 \mathrm{~Hz}$ measurement and data logging frequency using the EEPS.

\section{Methodology}

The experiments were performed on a Euro VI HD engine. The control for the wastegate of the turbocharger was disengaged throughout the experiments. Also, the exhaust brake was not used. At all operating points, fuel was injected at TDC. Experiments were designed to sweep the SCR inlet conditions to affect the particle formation. The exhaust conditions considered here were urea injection quantities, temperature at the inlet of the SCR, exhaust mass flow rate through the SCR, and particle concentration/ $\mathrm{NO}_{\mathrm{x}}$ at the inlet of the SCR. Urea quantity injected to the SCR was varied by varying the rate of AdBlue (32.5\% Urea+ deionized water) injection. AdBlue was injected through the urea dosing system in steps of $25 \mathrm{~g} / \mathrm{min}$. AdBlue injection was increased until the $\mathrm{NO}_{\mathrm{x}}$ at the SCR outlet (SCR OUT $\mathrm{NO}_{\mathrm{x}}$ ) was fully reduced. The temperatures evaluated at the inlet of the SCR (SCR IN temperature) were $300^{\circ} \mathrm{C}$ and $400^{\circ} \mathrm{C}$. The evaluated exhaust mass flow rates through the SCR were $225 \mathrm{~g} / \mathrm{s}, 250 \mathrm{~g} / \mathrm{s}$ and $275 \mathrm{~g} / \mathrm{s}$. These have been denoted in Figure 3 . Hence in this study, SCR is the system of interest and the design of the experiments was with respect to the SCR and not the engine conditions. The total PN was varied by altering the injection pressures. In addition, it is to be noted that not only the PN but also $\mathrm{NO}_{\mathrm{x}}$ out of the engine varies with injection pressures $[13,14]$. Higher the injection pressure, lesser is the total PN emission [13] and higher is the $\mathrm{NO}_{\mathrm{x}}$ emission [14]. At lower injection pressures it is the vice versa. Thus experiments were performed at same operating points of SCR IN temperature and exhaust mass flow rates across the SCR with different fuel injection pressures namely 800 bar and 1200 bar. Hence a total of 12 operating points were performed in this experimental campaign.

To evaluate the effect of deionized water on the SCR system, the operating points of exhaust flow rate of $225 \mathrm{~g} / \mathrm{s}$ for SCR IN temperatures of $300^{\circ} \mathrm{C}$ and $400^{\circ} \mathrm{C}$; and fuel injection pressures 800 bar and 1200 bar were chosen since these points have the most residence time. Deionized water was injected through the urea dosing system (same as urea injection quantities in steps of $25 \mathrm{~g} / \mathrm{min}$ ).

\section{FIGURE 3 Design of Experiments}

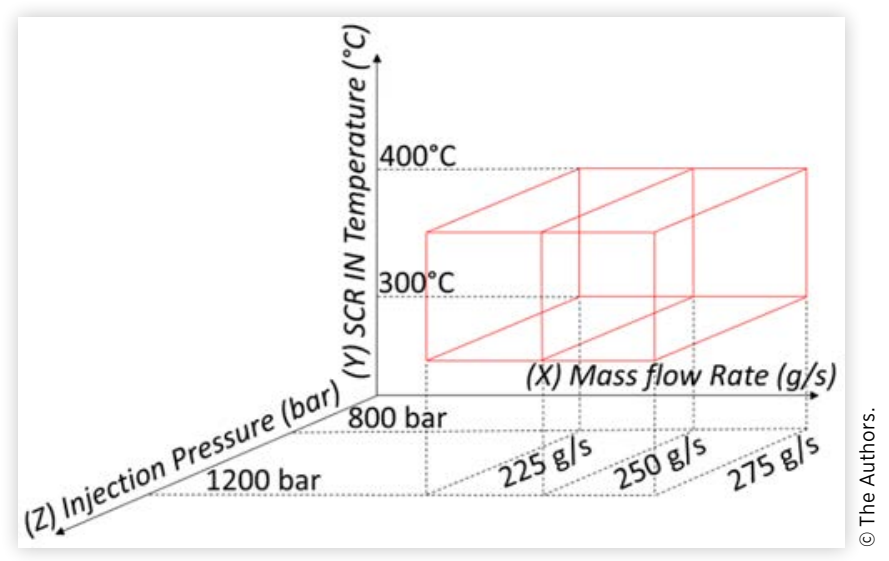


The experiments were conducted by varying the speed and torque of the engine, causing to vary the exhaust conditions. The speed was initially fixed and then the torque was increased so that the SCR IN temperatures was maintained constant. Later, the speed was increased and the process was repeated for higher flow rates of the exhaust. The order of the operating point's execution was in the order of DPF filling, leading to lesser particles at the inlet of SCR as the experiment progresses. Hence first, experiment was conducted for higher SCR IN temperature $\left(400^{\circ} \mathrm{C}\right)$. At higher SCR IN temperature, the injection pressure was swept from higher to lower value because the engine out particles increases with lower injection pressure as explained earlier. Then lower to higher flow rates were swept.

Higher exhaust temperature causes regeneration of the DPF [15]. On the other hand, increasing flow rates cause an increased soot loading of the DPF [15]. Similarly, the same order was repeated for the lower SCR IN temperature $\left(300^{\circ} \mathrm{C}\right)$ to have less particles from the regeneration of the DPF. The exhaust flow rate was calculated as the sum of mass flow rate of air and diesel $\left(\dot{\mathrm{m}}_{\mathrm{air}}+\dot{\mathrm{m}}_{\text {diesel }}\right)$.

In Figure 3 , along the constant SCR IN temperature line, operating points analyzed in the direction of $\mathrm{x}$-axis describes the effect of mass flow rate. Similarly, along a constant mass flow rate line, operating points are analyzed in the direction of $y$-axis describes the effect of SCR IN temperature. All measurements at each operating point were performed at steady state of engine operation.

\section{Data Analysis}

In these experiments, $\mathrm{NO}_{\mathrm{x}}$ and $\mathrm{PN}$ measurements were made at inlet of the SCR (1) and outlet of the ASC (2) as shown in Figure 1. The change in $\mathrm{NO}_{\mathrm{x}}$ between inlet and outlet with respect to inlet (in \%) was calculated as shown in Equation (1).

$$
\text { Change in } \mathrm{NO}_{x}(\%)=\frac{\text { Oulet } \mathrm{NO}_{x}-\text { Inlet } \mathrm{NO}_{x}}{\text { Inlet } N O_{x}} \cdot 100
$$

The change in total PN between inlet and outlet with respect to inlet $\left(\# / \mathrm{cm}^{3}\right)$ was calculated as shown in Equation (2).

$$
\text { Change in } P N=\text { Oulet } P N-\operatorname{Inlet} P N\left(\# / \mathrm{cm}^{3}\right)
$$

Change in $\mathrm{PN}$ is positive when there is an increase in the total number of particles across the SCR; on the other hand if the value is negative then there is a decrease in the total number of particles across the SCR. The change in PN was made as difference between outlet $\mathrm{PN}$ and inlet PN. The change was not made as percentage because the inlet $\mathrm{PN}$ value depends on the loading of the DPF. Each measurement was taken for three sampling trials. Each trial was taken for 120 seconds at $1 \mathrm{~Hz}$ frequency as described earlier. Thus, each engine operating point had 360 measurement points. All three trials were merged and averaged for the actual PN for each operating point. The PN values from CPC1 substituted in equation (2) was used to calculate the results for change in $\mathrm{PN}$ $(>23 \mathrm{~nm})$. The difference in $\mathrm{PN}$ values of $\mathrm{CPC} 2$ and $\mathrm{CPC} 1$ yields the PN $(7-23 \mathrm{~nm})$. Later, it was substituted in equation (2) was used to calculate the results for change in PN $(7-23 \mathrm{~nm})$.

\section{Results}

The results from the experiments are described here under three headings namely:

i. $\mathrm{NO}_{\mathrm{x}}$ reduction across the SCR.

ii. Change in PN across the SCR on accumulation mode particles and further (particle size $>23 \mathrm{~nm}$ ).

iii. Change in PN across the SCR on nucleation mode particles (particle size between 7-23 $\mathrm{nm}$ ).

All measurements across the SCR denotes the measurements across the SCR including the ASC and henceforth mentioned as measurement across SCR.

\section{$\mathrm{NO}_{\mathrm{x}}$ Reduction across the SCR}

First, an analysis was made to evaluate the change in $\mathrm{NO}_{\mathrm{x}}(\%)$ emission across the SCR at different operating conditions. The values are negative as there is an effective reduction of $\mathrm{NO}_{x}$ concentration across the SCR. Hence the term $\mathrm{NO}_{\mathrm{x}}$ reduction is also used for the change in $\mathrm{NO}_{\mathrm{x}}(\%)$ emission across the SCR.

The results of the NOx emission reduction across the SCR at $400^{\circ} \mathrm{C}$ with fuel injection pressure $1200 \mathrm{bar}$ and $800 \mathrm{bar}$ is given in Figure 4a and Figure 4b. The lowest and highest values of raw $\mathrm{NO}_{\mathrm{x}}$ emission for the three flow rates is given as a range near the no urea injection point $(0 \mathrm{~g} / \mathrm{min})$ near the $\mathrm{x}$-axis for better understanding. The variation of urea injection was made in steps of $25 \mathrm{~g} / \mathrm{min}$, and hence $100 \% \mathrm{NO}_{\mathrm{x}}$ reduction can be confirmed only in terms of the same step value. From

\section{FIGURE 4 Change in $\mathrm{NO}_{x}(\%)$ across the SCR at $400^{\circ} \mathrm{C}$}

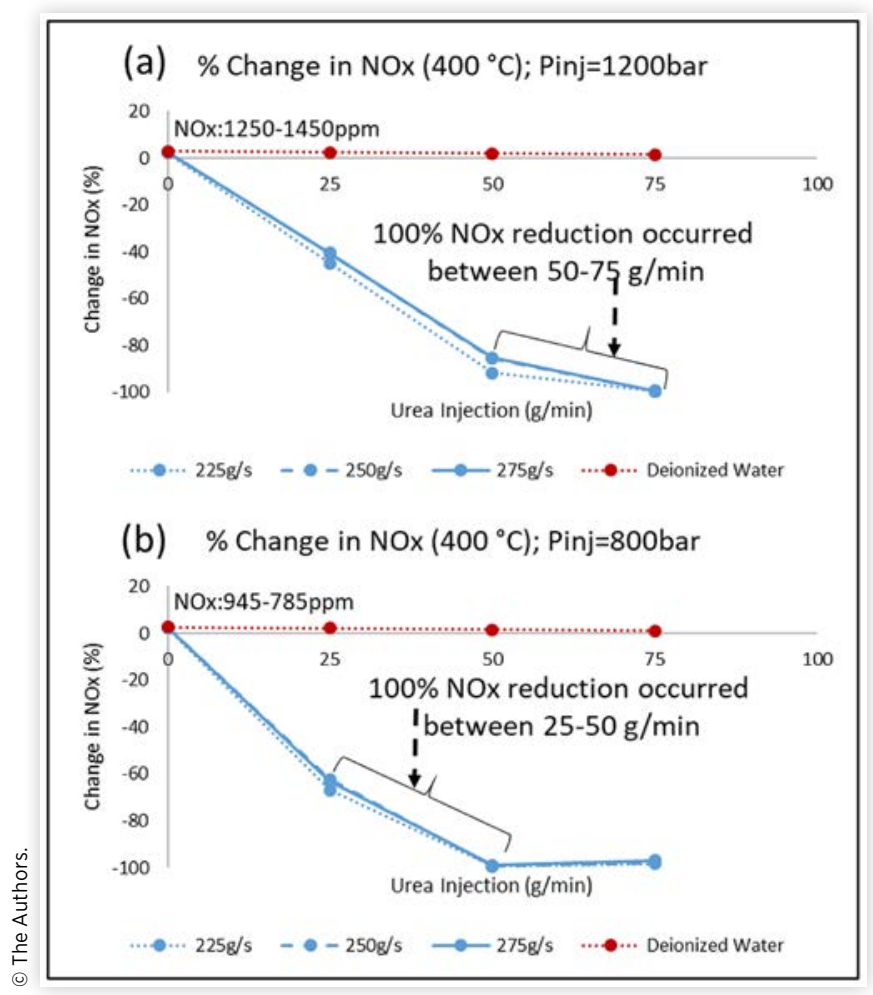


the figures it can be observed that the $\mathrm{NO}_{\mathrm{x}}$ emission reduces as the urea quantity is increased. Almost insignificant $\mathrm{NO}_{\mathrm{x}}$ reduction was observed at no urea injection (dry run SCR). Furthermore, comparing Figure 4a and Figure 4b it can be noticed that $100 \% \mathrm{NO}_{\mathrm{x}}$ reduction occurred between $50-75 \mathrm{~g} / \mathrm{min}$ at 1200 bar fuel injection pressure whilst the same was observed between $25-50 \mathrm{~g} / \mathrm{min}$ at 800 bar. As described earlier in the methodology, higher fuel injection pressure results in higher engine out $\mathrm{NO}_{\mathrm{x}}$ emission. Hence the urea requirement needed for complete $\mathrm{NO}_{\mathrm{x}}$ reduction was lower at 800 bar than at 1200 bar. (see Figure $4 \mathrm{a}$ and Figure $4 \mathrm{~b}$ ). In addition, the exhaust flow rate through the SCR does not seem to affect the $\mathrm{NO}_{\mathrm{x}}$ reduction as all the blue lines almost merged with each other (see Figure 4a and Figure 4b). From the red dotted line in Figure 4a and Figure 4b, it is evident that there is no change in $\mathrm{NO}_{\mathrm{x}}$ emission across the SCR when operated with deionized water.

Figure $5 \mathrm{a}$ and Figure $5 \mathrm{~b}$ shows the $\mathrm{NO}_{\mathrm{x}}$ reduction at $\mathrm{SCR}$ IN temperature of $300^{\circ} \mathrm{C}$ with fuel injection pressure of 1200 bar and 800 bar. The lowest and highest values of raw $\mathrm{NO}_{\mathrm{x}}$ emission for the three flow rates is given as a range near the no urea injection point $(0 \mathrm{~g} / \mathrm{min})$ near the $\mathrm{x}$-axis for better understanding. From Figure $5 \mathrm{a}$ and Figure $5 \mathrm{~b}$, it can be seen that the urea injection quantities was made up to $50 \mathrm{~g} / \mathrm{min}$ as the $100 \% \mathrm{NO}_{\mathrm{x}}$ reduction was reached within this value. As a result of the lower exhaust temperature $\left(300^{\circ} \mathrm{C}\right)$, the $\mathrm{NO}_{\mathrm{x}}$ emission from the engine was lower as the engine loads were lower in comparison to the loads at exhaust temperature of $400^{\circ} \mathrm{C}$. Hence the urea injection quantity needed for $\mathrm{NO}_{\mathrm{x}}$ reduction was lower when compared with urea injection quantity at $400^{\circ} \mathrm{C}$. A comparison between Figure 5a and

\section{FIGURE 5 Change in $\mathrm{NO}_{x}(\%)$ across the $\mathrm{SCR}$ at $300^{\circ} \mathrm{C}$}

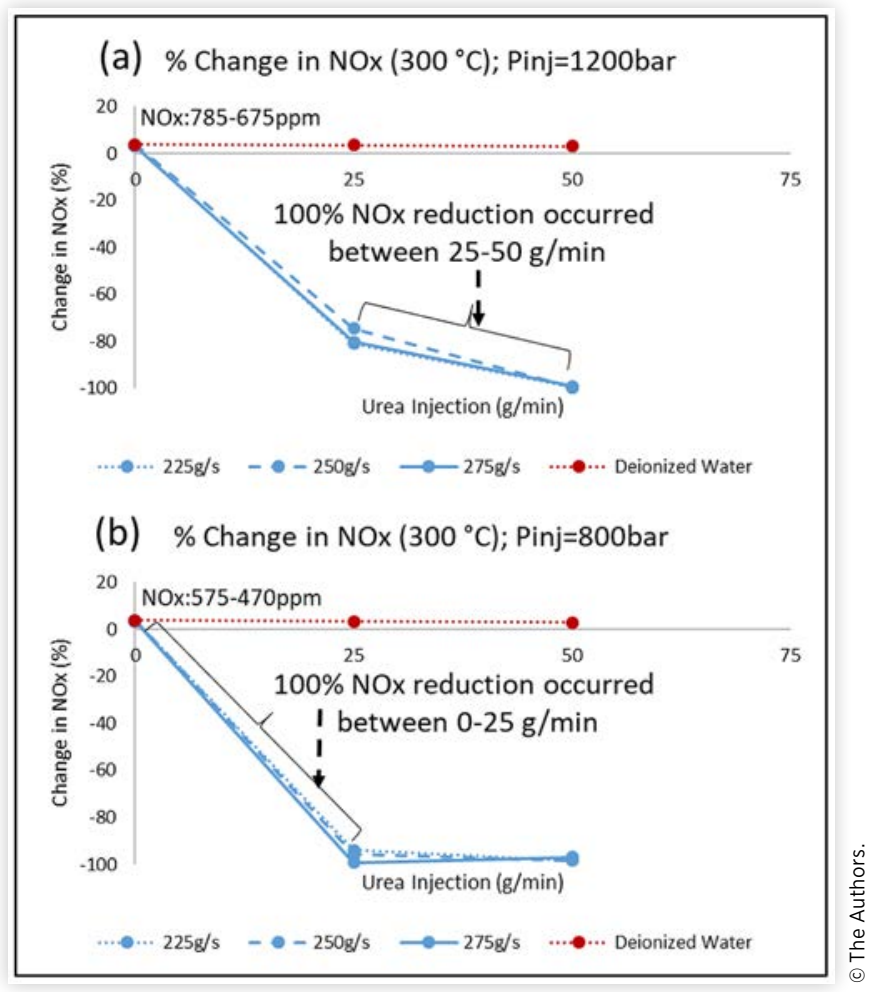

Figure $5 \mathrm{~b}$ shows that $100 \% \mathrm{NO}_{\mathrm{x}}$ reduction occurred between $25-50 \mathrm{~g} / \mathrm{min}$ at $1200 \mathrm{bar}$ (fuel injection pressure) whilst the same was observed between $0-25 \mathrm{~g} / \mathrm{min}$ at $800 \mathrm{bar}$ (fuel injection pressure). Similar to the observation at $400^{\circ} \mathrm{C}$, from Figure $5 \mathrm{a}$ and Figure $5 \mathrm{~b}$, it can be clearly observed from the red dotted line that there is no change in $\mathrm{NO}_{\mathrm{x}}$ emission across the SCR when operated with deionized water.

\section{Change in PN across the SCR on Accumulation Mode Particles and Further (Particle Size $>23 \mathrm{~nm}$ )}

The change in PN (>23 nm) across the SCR was measured to study the accumulation mode particles and particles further in size. The change in PN across the SCR is shown in absolute number difference between the outlet PN and inlet PN as calculated using Equation (2).

The results with respect to the change in PN $(>23 \mathrm{~nm})$ across the SCR in Figure 6. Within Figure 6, sub-figures a, b and $\mathrm{c}$ corresponds to the change in PN at 1200 bar across the SCR at different flow rates; sub-figures $\mathrm{d}$, e and $\mathrm{f}$ corresponds to the change in PN at 800 bar across the SCR at different flow rates. Each sub-figure shows the effect of urea injection on PN $(>23 \mathrm{~nm})$ at two different temperatures.

For the flow rate of $225 \mathrm{~g} / \mathrm{s}$, results are shown with the deionized water injection using solid and dashed red-lines (see Figure 6a and Figure 6d).

From Figure 6a, Figure 6b and Figure $6 \mathrm{c}$ it can be clearly seen that at an SCR IN temperature of $400^{\circ} \mathrm{C}$, there is a PN increase of about $2-4 \mathrm{e}+4 \# / \mathrm{cm}^{3}$ across the SCR with higher urea injection quantities. With the same urea injection quantity, at $300^{\circ} \mathrm{C}$, the increase was less in magnitude. This could be due to the salt formation in SCR at high temperatures as discussed earlier. Furthermore, the increase in PN was not observed when there is no urea injection $(0 \mathrm{~g} / \mathrm{min})$. Cutting across different exhaust flow rates in Figure 6 (comparing sub figures a, b and c; comparing sub figures $d$, e and f) no clear trend was noticed. The above findings could be confirmed as it was observed with both the dilution systems, DS1 and DS2.

Figure 6a shows that the effect of deionized water injection at 1200 bar and shows no change in PN across the SCR at $400^{\circ} \mathrm{C}$. Contrary to urea injection, with deionized water, there was neither an increase nor a decrease in PN noticed across the SCR at $400^{\circ} \mathrm{C}$. At the same time, there was a reduction (of about $1 \mathrm{e}+4 \# / \mathrm{cm}^{3}$ ) in $\mathrm{PN}$ observed at $300^{\circ} \mathrm{C}$. The water droplet stays longer than at $400^{\circ} \mathrm{C}$ causing particles to stick together and later drying with particles sticking together which in turn reduces the PN concentration at the outlet of the SCR.

From Figure 6a, Figure 6b and Figure $6 \mathrm{c}$ it can be noted that the trends of the all curves with DS2 is similar to that of DS1. It can as well be noted that DS2 was always under valuing the PN when compared to DS1 but still it was closer to the PN values of DS1. The exception is at the higher urea injection values. 


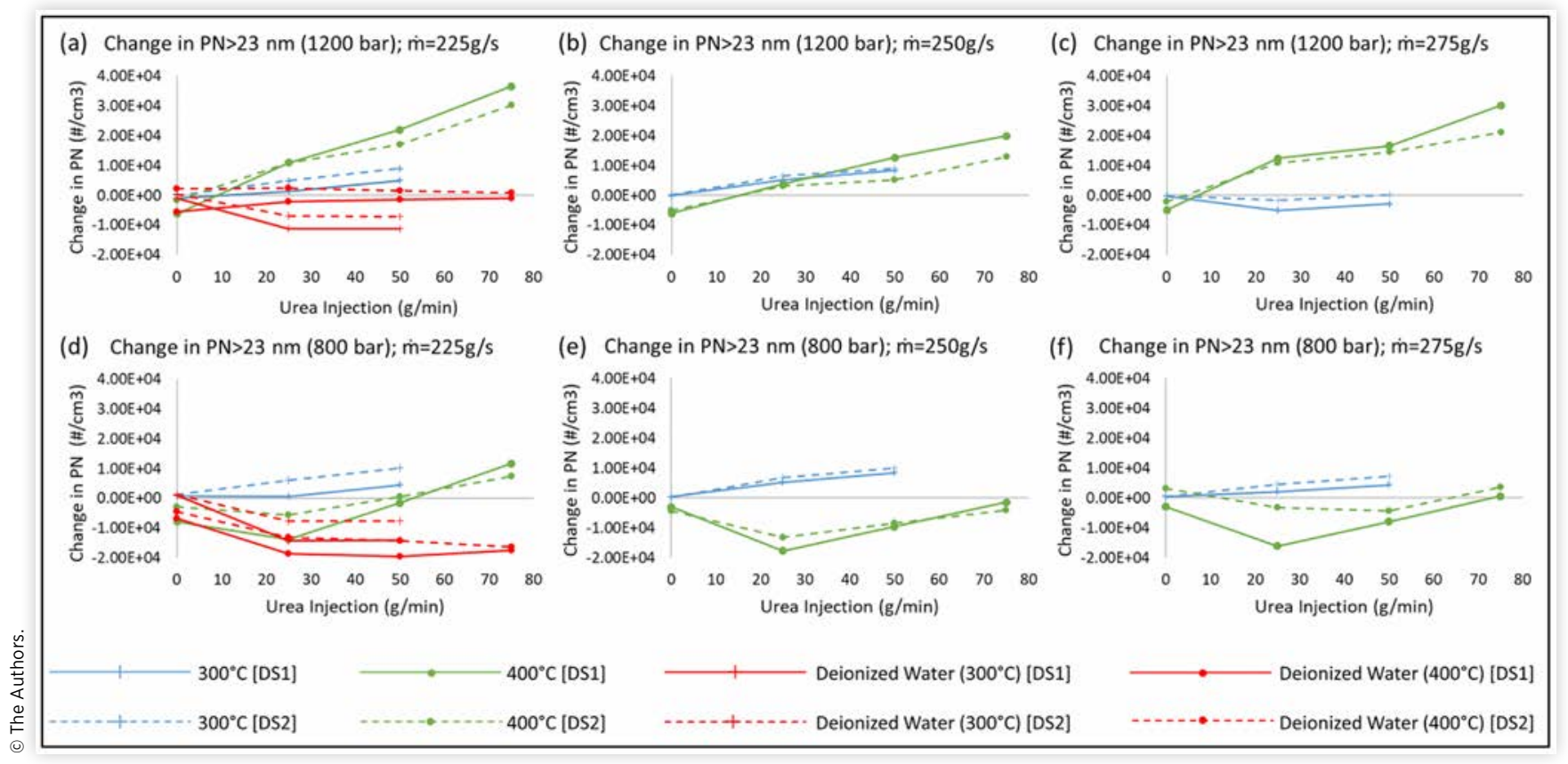

The analysis for PN ( $>23 \mathrm{~nm}$ ) with respect to injection pressure $800 \mathrm{bar}$ is presented as follows. From the results shown in Figure 6d, Figure 6e and Figure 6f, it can be noted that the increase in PN was not observed with SCR IN temperature of $400^{\circ} \mathrm{C}$, in spite of same urea injection quantities. On the other hand, a decrease in $\mathrm{PN}$ of about $2 \mathrm{e}+4 \# / \mathrm{cm}^{3}$ was noticed with urea injection and with a further increase, the reduction in $\mathrm{PN}$ decreased. This might be due the water droplets reducing the inlet $\mathrm{PN}$ to SCR since there could be greater regeneration of the $\mathrm{DPF}$ at $400^{\circ} \mathrm{C}$. The reason is higher amounts of soot particles entering the DPF also get emitted as compared to 1200 bar. With excess urea, salt formation might increase. Whereas at $300^{\circ} \mathrm{C}$, the same condition was not observed and DPF could be clogged. Hence there was a less pronounced increase with SCR IN temperature of $300^{\circ} \mathrm{C}$.

The effect of deionized water injection at 800 bar is shown Figure 6d. SCR inlet $\mathrm{PN}$ is higher at 800 bar and $400^{\circ} \mathrm{C}$ in comparison to the $1200 \mathrm{bar}$ and $400^{\circ} \mathrm{C}$ due to higher engine out emissions [13]. Hence, the $\mathrm{PN}$ reduction was observed due to the water droplets effect. The droplets could be with deionized water causing to reduce the PN at the outlet of SCR. Hence, the magnitude of reduction of PN was higher when compared to 1200 bar (see Figure 6a and Figure 6d). Furthermore, the reduction in $\mathrm{PN}$ at 800 bar observed at SCR IN temperatures of $300^{\circ} \mathrm{C}$ was similar to $1200 \mathrm{bar}$. The reason could be lesser particles at SCR inlet due to lesser regeneration of the DPF and more clogged at $300^{\circ} \mathrm{C}$.

The results with respect to fuel injection pressure $800 \mathrm{bar}$ using dilution systems DS1 and DS2 were similar (see Figure 6d, Figure 6e and Figure 6f). By comparison it can be noticed that the difference between DS1 and DS2 was in the magnitude of PN.

\section{Change in PN across the SCR on Nucleation Mode Particles and Further (7-23 nm)}

The analysis for PN (7-23 nm) was made to analyse the nucleation particles. The change in $\mathrm{PN}(7-23 \mathrm{~nm})$ was calculated by the difference in $\mathrm{PN}$ values of $\mathrm{CPC} 2$ and $\mathrm{CPC} 1$ yielding the PN $(7-23 \mathrm{~nm})$ values. Later, the values were substituted in equation (2) to calculate the results for change in $\mathrm{PN}(7-23 \mathrm{~nm})$ as explained in data analysis section.

The results with respect to the change in PN $(7-23 \mathrm{~nm})$ across the SCR in Figure 7. Within Figure 7, sub-figures a, b and $\mathrm{c}$ corresponds to the change in PN at 1200 bar across the SCR at different flow rates; sub-figures $\mathrm{d}$, e and $\mathrm{f}$ corresponds to the change in $\mathrm{PN}$ at 800 bar across the SCR at different flow rates. Each sub-figure shows the effect of urea injection on PN $(7-23 \mathrm{~nm})$ at two different temperatures. The graphs have a $y$-axis to fit the extreme value points. The extreme points are shown by values in data labels.

For the flow rate of $225 \mathrm{~g} / \mathrm{s}$, results are shown with the deionized water injection using solid and dashed red-lines (see Figure 7a and Figure 7d).

From Figure 7a, Figure $7 \mathrm{~b}$ and Figure $7 \mathrm{c}$ it can be evidently seen that at an SCR IN temperature of $400^{\circ} \mathrm{C}$ and injection pressure of 1200 bar, the magnitude of change in PN showing a sudden increase in PN of nucleation particles across the SCR beyond urea injection quantity of $50 \mathrm{~g} / \mathrm{min}$ which corresponds to $100 \% \mathrm{NO}_{\mathrm{x}}$ reduction (see Figure 4a). On other hand, with the same urea injection quantities, at $300^{\circ} \mathrm{C}$ such sudden increase was not observed. As the increase was drastic for SCR IN temperature of $400^{\circ} \mathrm{C}$, the scale of $y$-axis was very high making the $300^{\circ} \mathrm{C}$ curve to trail near the $\mathrm{x}$-axis. Also, there 


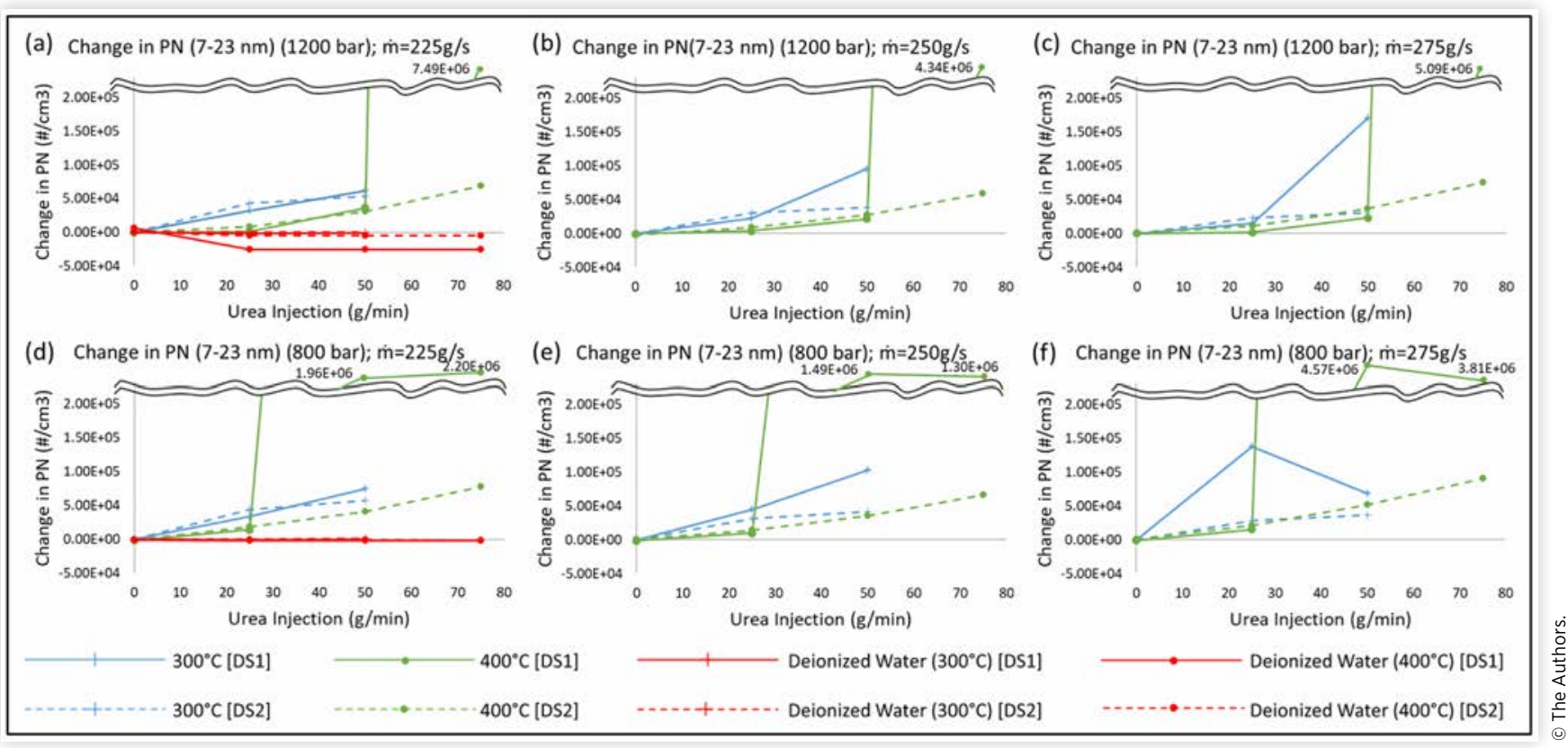

was gradual increasing trend observed in PN across the SCR at urea injection quantity up to $50 \mathrm{~g} / \mathrm{min}$.

With different exhaust flow rates in Figure 7 (comparing sub figures a, b and c; comparing sub figures $d$, e and f) no clear trend could be noticed and hence can be confirmed as it was observed with both the dilution systems, DS1 and DS2.

In Figure 7, the solid and dotted lines indicate the PN measurements with DS1 and DS2 respectively. From Figure 7 (comparing sub figures a, b and c; comparing sub figures d, e and f) it can be seen that the sudden increase in PN was not observed using the DS2 and instead a gradual increasing trend was observed at $400^{\circ} \mathrm{C}$ with higher urea injection quantities. This could be due to the sample conditioning differences between the dilution systems DS1 and DS2. There could be volatile components after primary dilution in DS2 and then coagulation of the particles due to the absence of evaporation tube causing a lesser increase in PN measurements.

Figure 7a shows the effect of deionized water injection at 1200 bar. The results show a reduction on PN of nucleation particles (of about $3 \mathrm{e}+4 \# / \mathrm{cm}^{3}$ ) while the SCR was operated at $400^{\circ} \mathrm{C}$ with deionized water. This could be because of regeneration of DPF and particles emitted from the DPF. The engine out particles from 1200 bar are smaller than at 800 bar [13] and hence the regenerated particles could also be smaller and got noticed in PN (7-23 nm) measurements. This was not noticed at $300^{\circ} \mathrm{C}$ as the DPF regeneration could be less. The reason for reduction could be the droplets sticking to particles in the SCR.

The analysis for PN (7-23 nm) with respect to injection pressure 800 bar is presented in Figure 7d, Figure 7e and Figure $7 \mathrm{f}$. It can be clearly seen that at an SCR IN temperature of $400^{\circ} \mathrm{C}$ and injection pressure of 800 bar, the magnitude of change in PN shows a sudden increase across the SCR beyond urea injection quantity of $25 \mathrm{~g} / \mathrm{min}$. It can be recollected from Figure $4 \mathrm{~b}$ that it corresponds to $100 \% \mathrm{NO}_{\mathrm{x}}$ reduction. Hence the sudden increase at $400^{\circ} \mathrm{C}$ using DS1 matches with excess urea injection quantities. Conversely, the sudden increase in
PN was not observed with SCR IN temperature of $300^{\circ} \mathrm{C}$, in spite of same urea injection quantities. Also, there was a gradual increasing trend observed in PN across the SCR up to the urea injection quantity of $50 \mathrm{~g} / \mathrm{min}$.

Figure $7 \mathrm{~d}$ shows the change in PN with regard to nucleation particles at 800 bar compared with deionization water injection. No reduction in nucleation $\mathrm{PN}$ with deionized water injection was noticed. This could be due to lesser nucleation particles emitted from the engine at 800 bar when compared to 1200 bar, and, also due to higher PN to DPF, trapping the nucleation particles in the DPF.

The measurements with the EEPS is presented for $400^{\circ} \mathrm{C}$ in Figure 8. Particle Number distribution with AdBlue injection is shown in sub-plots a and b. Particle Number distribution with deionized water injection is shown in sub-plots $c$ and d. From Figure 8a, it can be observed that at 1200 bar of fuel injection pressure, with urea injection, particle increases both in nucleation and accumulation. On the other hand, higher urea quantities did not continually increase the particles. Surprisingly, particle increase was seen with the EEPS when using deionized water but is not corroborated by the CPC measurements particle increase was noticed. Figure $8 \mathrm{~b}$ and Figure 8d shows no change in particles across the SCR with fuel injection pressure of 800 bar.

It is possible that the inbuilt soot inversion matrix in EEPS was not capturing the particle change across the SCR appropriately as these are salt particles. So further conclusions could not be drawn from the EEPS results.

\section{Discussion}

An experiment testing the effect of various inlet conditions of SCR was performed and the results were presented and the inferences are made from the results as follows. 

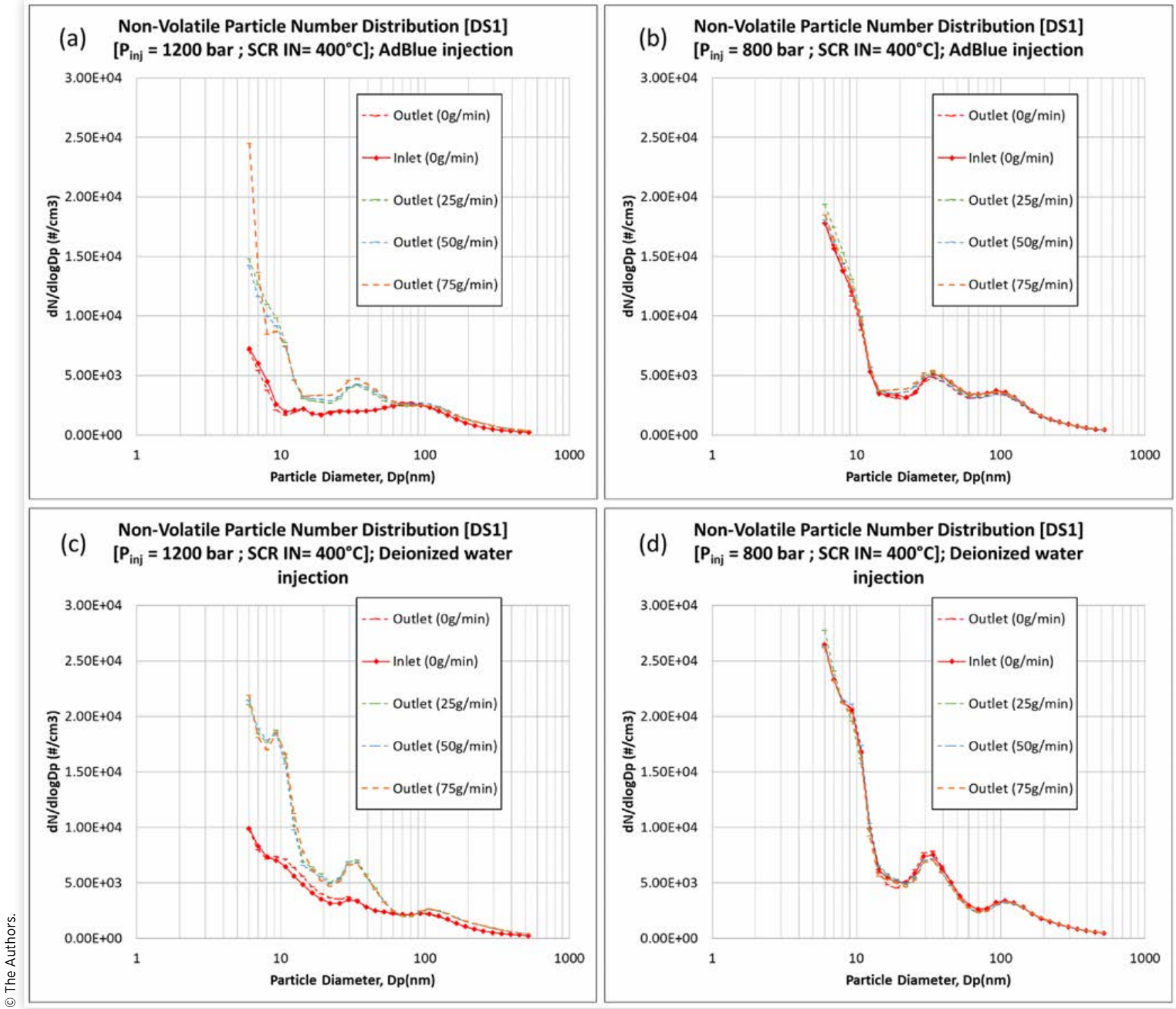

(d) Non-Volatile Particle Number Distribution [DS1]

(d) $\left[P_{\text {inj }}=800\right.$ bar ; SCR IN $\left.=400^{\circ} \mathrm{C}\right]$; Deionized water injection

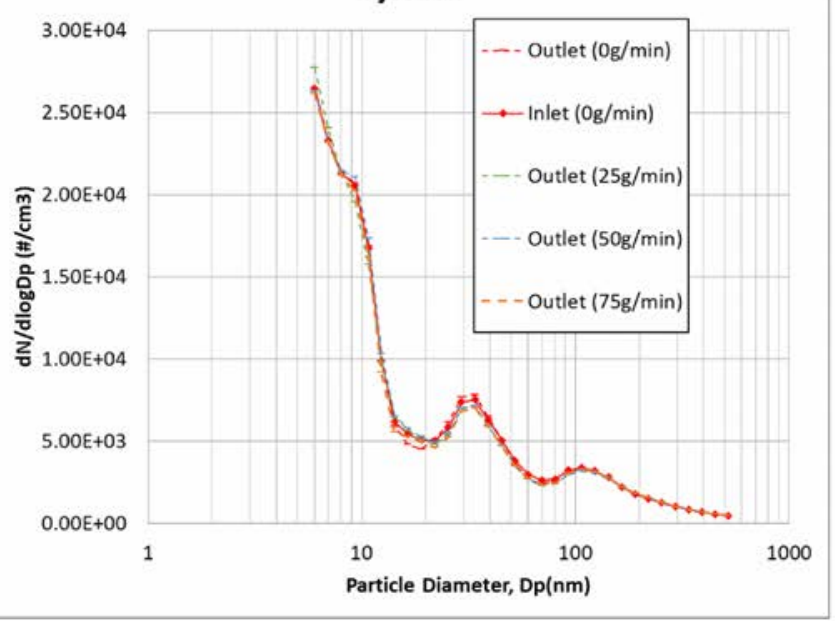

Higher urea injection quantities to the SCR increase the salt formation as the concentration of ammonia increases and the results confirm the increase in PN across the SCR using both the dilution systems.

Higher temperatures at the SCR inlet are due to higher engine loads and aid the reaction of ammonium salt formation due to high reaction temperatures [11]. The accelerated salt formation rate was leading to higher PN at SCR outlet but the finding cannot be generalized as it depends on the inlet $\mathrm{NO}_{\mathrm{x}}$ concentration to the SCR. Excess urea injection events at $400^{\circ} \mathrm{C}$ lead to drastic increase of nucleation PN. Only DS1 could measure this phenomenon and the reason is unclear. One possible reason could be the presence of evaporation tube in DS1, ensures non-volatile nucleation particles to be distinct for measurement, while in DS2, the nucleation particles was not be dry enough after dilution and may have coagulated before measurement [16]. The particles could be salts or unreacted urea $[\underline{10}, \underline{11}]$.

Higher mass flow rates through the SCR had little effect on $\mathrm{NO}_{\mathrm{x}}$ reduction. This led to the inference that the residence time and space velocity was not affecting the $\mathrm{NO}_{\mathrm{x}}$ conversions at higher temperatures $\left(300^{\circ} \mathrm{C}\right.$ and $\left.400^{\circ} \mathrm{C}\right)$, which was also noted by Han et al. [17]. The same was reflected in the PN change across the SCR, i.e., residence time and space velocity had little or no influence in PN change across the SCR, at exhaust temperatures of $300^{\circ} \mathrm{C}$ and $400^{\circ} \mathrm{C}$.

Higher fuel injection pressures led to higher $\mathrm{NO}_{\mathrm{x}}$ and lower PN from the engine, so higher SCR inlet $\mathrm{NO}_{\mathrm{x}}$ concentration may favour nitrate salt formation, in turn leading to higher increase in PN across the SCR.

With deionized water injection in the SCR, $\mathrm{NO}_{\mathrm{x}}$ was unchanged and $\mathrm{PN}$ increase was not observed as there was no ammonia to promote salt formation. On the other hand, deionized water led to $\mathrm{PN}$ reduction when the inlet $\mathrm{PN}$ is higher. This was observed when the temperatures was high and causing passive DPF regeneration. The resulting particles from DPF 
TABLE 2 Inferences on change in PN (>23nm) across the SCR

\begin{tabular}{|c|c|c|c|}
\hline Temperature $\left({ }^{\circ} \mathrm{C}\right)$ & DS1 & DS2 & Net Conclusion \\
\hline $300^{\circ} \mathrm{C}$ & $\begin{array}{l}\text { No significant change was } \\
\text { observed with increase in urea } \\
\text { injection quantities }\end{array}$ & $\begin{array}{l}\text { No significant change was } \\
\text { observed with increase in urea } \\
\text { injection quantities }\end{array}$ & $\begin{array}{l}\text { No significant change across } \\
\text { the SCR with increase in urea } \\
\text { injection quantities }\end{array}$ \\
\hline \multirow[t]{2}{*}{$400^{\circ} \mathrm{C}$} & $\begin{array}{l}\text { Increase in PN observed with } \\
\text { increase in urea injection } \\
\text { quantities at } 1200 \text { bar }\end{array}$ & $\begin{array}{l}\text { Increase in PN observed with } \\
\text { increase in urea injection } \\
\text { quantities at } 1200 \text { bar }\end{array}$ & $\begin{array}{l}\text { At } 1200 \text { bar increase in PN } \\
\text { across the SCR with increase } \\
\text { in urea injection quantities }\end{array}$ \\
\hline & $\begin{array}{l}\text { No significant change was } \\
\text { observed with increase in urea } \\
\text { injection quantities at } 800 \text { bar }\end{array}$ & $\begin{array}{l}\text { No significant change was } \\
\text { observed with increase in urea } \\
\text { injection quantities at } 800 \text { bar }\end{array}$ & $\begin{array}{l}\text { No significant change across } \\
\text { the SCR with increase in urea } \\
\text { injection quantities at } 800 \text { bar }\end{array}$ \\
\hline Temperature $\left({ }^{\circ} \mathrm{C}\right)$ & DS1 & DS2 & Net Conclusion \\
\hline $300^{\circ} \mathrm{C}$ & $\begin{array}{l}\text { Increase in PN was observed } \\
\text { with increase in urea injection } \\
\text { quantities }\end{array}$ & $\begin{array}{l}\text { Increase in PN was } \\
\text { observed with increase in } \\
\text { urea injection quantities }\end{array}$ & $\begin{array}{l}\text { Increase in PN across } \\
\text { the SCR was observed } \\
\text { with increase in urea } \\
\text { injection quantities }\end{array}$ \\
\hline $400^{\circ} \mathrm{C}$ & $\begin{array}{l}\text { (i) Increase in PN was observed } \\
\text { with increase in urea injection } \\
\text { quantities } \\
\text { (ii) Sudden increase in PN was } \\
\text { observed at excess urea } \\
\text { injection quantities }\end{array}$ & $\begin{array}{l}\text { Increase in PN was } \\
\text { observed with increase in } \\
\text { urea injection quantities }\end{array}$ & $\begin{array}{l}\text { Increase in PN across } \\
\text { the SCR was observed } \\
\text { with increase in urea } \\
\text { injection quantities }\end{array}$ \\
\hline
\end{tabular}

enter the SCR. In the SCR many particles cling to water droplets and finally dry up together leading to lower particles. This effect got saturated with the water injection quantities and did not continually decrease with increased injection quantities.

Measurement of the particle number distribution using EEPS did not lead to any solid inferences as the inbuilt soot inversion matrix in EEPS was not capturing the particle change across the SCR appropriately. The reason could be due to the salt particles from the SCR instead of soot particles, so further conclusions could not be drawn from the EEPS results.

The inferences for the change in PN for particles $>23 \mathrm{~nm}$ are shown in Table 2.

The inferences for the change in $\mathrm{PN}$ for nucleation particles between 7-23 $\mathrm{nm}$ are shown in Table 3 .

\section{Conclusions}

The experiment investigated the effect of various inlet conditions of SCR on PN change across the SCR of a Euro VI HD engine. The conclusions are made from the results as follows.

An increase in PN across the SCR occurs at $400^{\circ} \mathrm{C}$ with higher urea injection quantities accompanied with higher inlet $\mathrm{NO}_{\mathrm{x}}$ values due to the formation of nitrate salts. Otherwise, the higher temperature at the SCR inlet does not necessarily signify an increase in PN across the SCR. At the same time, an increase in nucleation particles was observed both at $300^{\circ} \mathrm{C}$ and $400^{\circ} \mathrm{C}$ with higher urea injection quantities, irrespective of the inlet $\mathrm{NO}_{\mathrm{x}}$ values due to the formation of ammonium salts. Furthermore, a sudden increase was observed only at $400^{\circ} \mathrm{C}$ for excess urea injection events, irrespective of the inlet $\mathrm{NO}_{\mathrm{x}}$ values due to the formation of ammonium salts or unreacted urea. This event was captured only by the particle dilution system with an evaporation tube. On the other hand, with deionized water injection, there was no decrease in $\mathrm{NO}_{\mathrm{x}}$ or increase in PN across the SCR as there was no ammonia to promote salt formation.

Flow rate across the SCR was not affecting the $\mathrm{NO}_{\mathrm{x}}$ reduction and PN increase across the SCR at all presented cases as the space velocity has low effect on the reaction kinetics of urea in the SCR at higher temperatures $\left(300^{\circ} \mathrm{C}\right.$ and $\left.400^{\circ} \mathrm{C}\right)$.

Appropriate particle number distribution measurements across the SCR was not captured by EEPS. The reason could be the in-built soot inversion matrix calibrated for soot particles while the particles from the SCR are salts.

Higher fuel injection pressures lead to increase in $\mathrm{NOx}$ and decrease in PN from the engine. The increased engine-out NOx is treated at the SCR but this treatment increases the PN thereby setting back the extent of the $\mathrm{PN}$ reduction attained in the engine leading to a $\mathrm{NOx}$ - PN trade-off at high temperatures.

\section{References}

1. Brook, R.D., Rajagopalan, S., Pope, C.A., Brook, J.R., et al., "Particulate Matter Air Pollution and Cardiovascular Disease: An Update to the Scientific Statement from the American Heart Association," Circulation 121(21):23312378, 2010, doi:10.1161/CIR.0b013e3181dbece1.

2. Donaldson, K., Li, X.Y., and MacNee, W., "Ultrafine (Nanometre) Particle Mediated Lung Injury," Journal of Aerosol Science 29(5-6):553-560, 1998, doi:10.1016/S00218502(97)00464-3.

3. Giechaskiel, B., Mamakos, A., Andersson, J., Dilara, P., et al., "Measurement of Automotive Nonvolatile Particle Number 
Emissions within the European Legislative Framework: A Review," Aerosol Science and Technology 46(7):719-749, 2012, doi: $10.1080 / 02786826.2012 .661103$.

4. Wang, X., Wang, Y., Bai, Y., Wang, P., et al., "An Overview of Physical and Chemical Features of Diesel Exhaust Particles," Journal of the Energy Institute 92(6):1864-1888, 2019, doi:10.1016/j.joei.2018.11.006.

5. Kittelson, D.B., Watts, W.F., Johnson, J.P., Rowntree, C.J., et al., "Driving down On-Highway Particulate Emissions," SAE Technical Paper 2006-01-0916, 2006, https://doi. org/10.4271/2006-01-0916.

6. Rönkkö, T., Virtanen, A., Kannosto, J., Keskinen, J., et al., "Nucleation Mode Particles with a Nonvolatile Core in the Exhaust of a Heavy Duty Diesel Vehicle," Environmental Science and Technology 41(18):6384-6389, 2007, doi:10.1021/ es0705339.

7. Thiruvengadam, A., Besch, M.C., Carder, D.K., Oshinuga, A., et al., "Influence of Real-World Engine Load Conditions on Nanoparticle Emissions from a DPF and SCR Equipped Heavy-Duty Diesel Engine," Environmental Science and Technology 46(3):1907-1913, 2012, doi:10.1021/es203079n.

8. Pietikäinen, M., Väliheikki, A., Oravisjärvi, K., Kolli, T., et al., "Particle and NOx Emissions of a Non-Road Diesel Engine with an SCR Unit: The Effect of Fuel," Renewable Energy 77:377-385, 2015, doi:10.1016/j.renene.2014.12.031.

9. Karjalainen, P., Ronkko, T., Lahde, T., Rostedt, A., et al., "Reduction of Heavy-Duty Diesel Exhaust Particle Number and Mass at Low Exhaust Temperature Driving by the DOC and the SCR," SAE Int. J. Fuels Lubr. 5(3):1114-1122, 2012, https://doi.org/10.4271/2012-01-1664.

10. Lee, S., Cho, Y., Song, M., Kim, H., et al., "Experimental Study on the Charcteristics of Nano-Particles Emissions from a Heavy-Duty Diesel Engine Using Urea-SCR System," International Journal of Automotive Technology 13(3):355363, 2012, doi:10.1007/s12239-012-0033-4.

11. Amanatidis, S., Ntziachristos, L., Giechaskiel, B., Bergmann, A., et al., "Impact of Selective Catalytic Reduction on Exhaust Particle Formation over Excess Ammonia Events," Environmental Science and Technology 48(19):11527-11534, 2014, doi:10.1021/es502895v.

12. Giechaskiel, B., Arndt, M., Schindler, W., Bergmann, A., et al., "Sampling of Non-Volatile Vehicle Exhaust Particles: A Simplified Guide," SAE Technical Paper 2012-01-0443, 2012, https://doi.org/10.4271/2012-01-0443.

13. Wu, B.Y., Zhan, Q., Zhang, S.K., et al., "Effect of Heavy-Duty Diesel Engine Operating Parameters on Particle Number and Size Distribution at Low Speed Condition," Int J Automot Technol 19(4):623-633, 2018, doi:10.1007/ s12239-018-0059-3.

14. Tan, X.G., Sang, H.L., Qiu, T., Fan, Z.Q., et al., "The Impact of Common Rail System's Control Parameters on the Performance of High-Power Diesel," Energy Procedia 16(PART C):2067-2072, 2011, doi:10.1016/j. egypro.2012.01.314.

15. Guan, B., Zhan, R., Lin, H., and Huang, Z., "Review of the State-of-the-Art of Exhaust Particulate Filter Technology in Internal Combustion Engines," Journal of Environmental Management 154:225-258, 2015, doi:10.1016/j. jenvman.2015.02.027.
16. Kasper, M., "The Number Concentration of Non-Volatile Particles - Design Study for an Instrument According to the PMP Recommendations," SAE Technical Paper 2004-010960, 2004, https://doi.org/10.4271/2004-01-0960.

17. Han, J., Kim, J., Jung, H., Pyo, S., et al., "Improvement of NOX Reduction Rate of Urea SCR System Applied for an Non-Road Diesel Engine," International Journal of Automotive Technology 20(6):1153-1160, 2019, doi:10.1007/ s12239-019-0108-6.

\section{Contact Information}

\author{
Arun Prasath K. \\ Competence Centre for Gas Exchange (CCGEx) \\ KTH Royal Institute of Technology \\ Brinellvägen 83, Stockholm, SE-10044, Sweden \\ karunpr@kth.se
}

\section{Acknowledgments}

The authors would like to thank Seshagopalan Thorapalli Muralidharan for his help in automating the experimental setup. This study was conducted as part of a project within the Competence Center for Gas Exchange (CCGEx) at KTH. The authors would like to acknowledge the Swedish Energy Agency, Volvo Cars, Volvo GTT, Scania, BorgWarner Turbo Systems Engineering, and Wärtsilä for their support and contributions.

\section{Definitions/Abbreviations}

\author{
ASC - Ammonia Slip Catalyst \\ CO - Carbon monoxide \\ CPC - Condensation Particle Counters \\ DOC - Diesel Oxidation Catalyst \\ Dp - Diameter of the particle \\ DPF - Diesel Particulate Filter \\ DS - Diesel System \\ EEPS - Engine Exhaust Particle Sizer Spectrometer \\ ESC - European Stationary Cycle \\ HC - Hydrocarbon \\ HD - Heavy-Duty \\ ICE - Internal Combustion Engines
}

ISO 8178 E2 - International Stationary engine testing cycle for marine application

LD - Light-duty

n - No. of Particles

$\mathrm{NH}_{3}$ - Ammonia

$\mathrm{NO}_{\mathbf{x}}$ - Oxides of Nitrogen

PMP - Particle Measurement Programme

PN - Particle Number

ppm - parts per million

SCR - Selective Catalytic Reduction unit 
SCR IN - Inlet of SCR unit

SCR OUT - Outlet of SCR unit
SEM - Scanning Electron Microscope

TDC - Top Dead Centre

\section{Appendix}

\section{Error Analysis for $\mathrm{NO}_{x}$ Measurements}

The $95 \%$ confidence interval of the $\mathrm{NO}_{\mathrm{x}}$ measurement was calculated using the expression shown below.

$$
\text { Actual } \mathrm{NO}_{x}(\text { ppm })=\text { Mean value } \pm 1.96 \frac{\sigma}{\sqrt{N}}
$$

Where,

$\sigma$ - Standard deviation of the measurement; $\mathrm{N}$ - Number of samples

The number of samples taken at each location for each operating point is 120 . The same was mentioned under the heading 'Sampling', " $\mathrm{NO}_{\mathrm{x}}$ measurements were taken at locations 1 and 2 using the engine $\mathrm{NO}_{\mathrm{x}}$ sensor at $1 \mathrm{~Hz}$ data logging frequency for 120 seconds."

Two sample points with high and low $\mathrm{NO}_{\mathrm{x}}$ values are shown for the error analysis. In both the points $\mathrm{NO}_{\mathrm{x}}$ measurements are shown with and without the urea injection for complete $\mathrm{NO}_{\mathrm{x}}$ reduction. The high change point for $\mathrm{NO}_{\mathrm{x}}$ is the point with 1200 bar fuel injection; SCR IN temperature $400^{\circ} \mathrm{C} ; 0$ and $75 \mathrm{~g} / \mathrm{min}$ urea injection; $\dot{\mathrm{m}}=225 \mathrm{~g} / \mathrm{s}$ of exhaust flow. The low change point is the point with $800 \mathrm{bar}$ fuel injection; SCR IN temperature $300^{\circ} \mathrm{C} ; 0$ and $50 \mathrm{~g} / \mathrm{min}$ urea injection; $\dot{\mathrm{m}}=225 \mathrm{~g} / \mathrm{s}$ of exhaust flow.
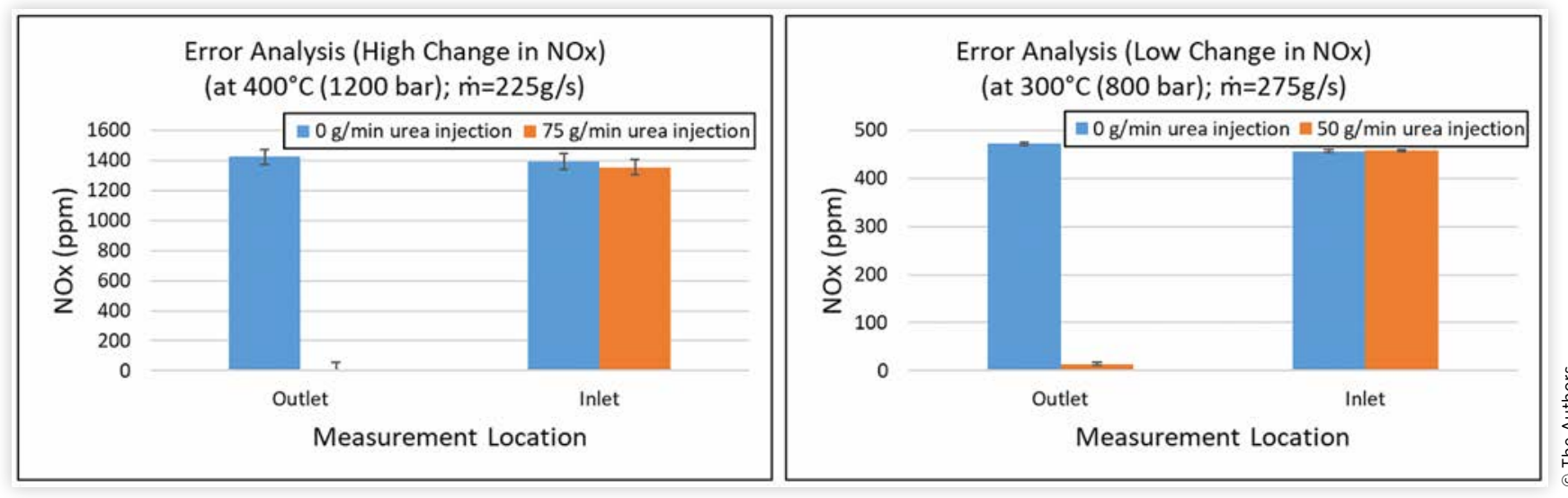

From the inlet and outlet values of $\mathrm{NO}_{\mathrm{x}}$ along with the error bars it can be seen that the change in $\mathrm{NO}_{\mathrm{x}}$ across the SCR with urea injection is significant and outside the error bars.

\section{Error Analysis for PN Measurements}

The 95\% confidence interval of the PN (>23 nm) measurement was calculated using the expression shown below.

$$
\text { Actual } P N\left(\# / \mathrm{cm}^{3}\right)=\text { Mean value } \pm 1.96 \frac{\sigma}{\sqrt{N}}
$$

Where,

$\sigma$ - Standard deviation of the measurement; $\mathrm{N}$ - Number of samples

The number of samples taken at each location for each operating point is 360 . The same was mentioned under the heading 'Particle Measurement System', "For each engine operating point, measurements were taken for three sampling periods to ensure repeatability. While measuring with the CPCs, each sampling period was 120 seconds, at $1 \mathrm{~Hz}$ measurement and data logging frequency". 
Two sample points are shown for the error analysis for both the dilution systems DS1 and DS2. The sample point taken are for high and low change in PN $(>23 \mathrm{~nm})$ across the SCR. The high change point is the SCR IN temperature $400^{\circ} \mathrm{C}$; $75 \mathrm{~g} / \mathrm{min}$ urea injection; $\dot{\mathrm{m}}=225 \mathrm{~g} / \mathrm{s}$ of exhaust flow. The low change point is the SCR IN temperature $400^{\circ} \mathrm{C} ; 25 \mathrm{~g} / \mathrm{min}$ urea injection; $\dot{\mathrm{m}}=225 \mathrm{~g} / \mathrm{s}$ of exhaust flow. The $95 \%$ confidence interval of the measurement is shown below with the error bars which is barely visible. Hence the figure is scaled from $6 \mathrm{e} 4$ for clarity.
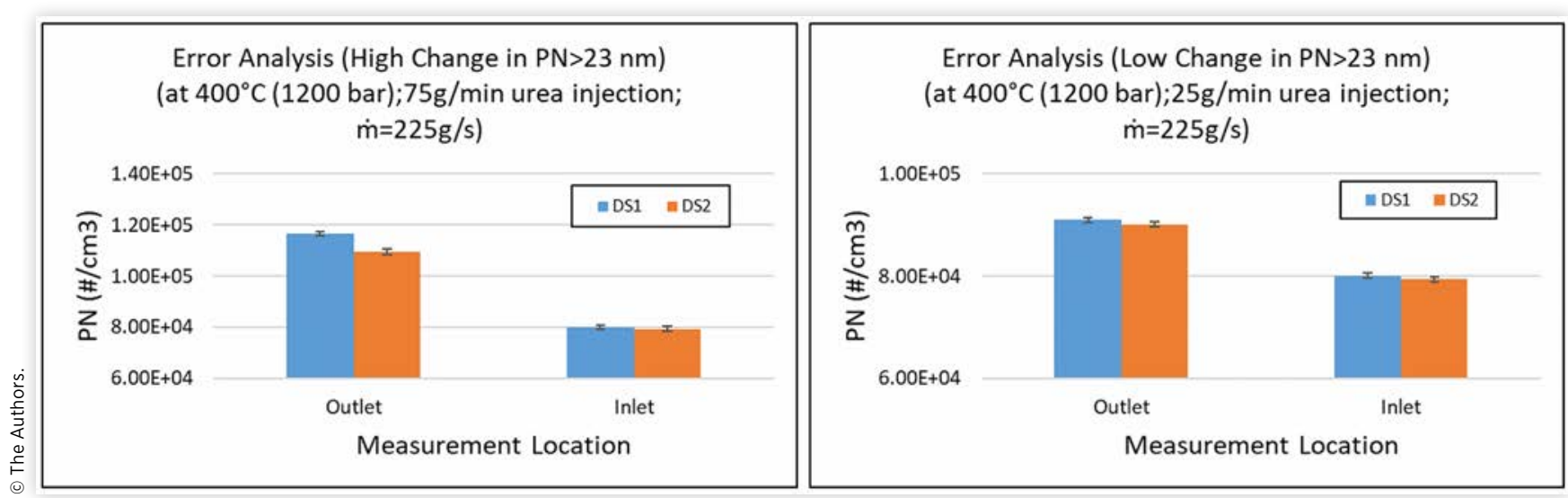

From the inlet and outlet values of PN along with the error bars it can be seen that the change in PN across the SCR with urea injection is significant and outside the error bars.

With regard to the change in PN (7-23 nm) across the SCR had a sharp spike in the measurements. The 95\% confidence interval may not be visible in a plot and hence not presented here.

(c) 2020 The Authors. Published by SAE International. This Open Access article is published under the terms of the Creative Commons Attribution License (http:// creativecommons.org/licenses/by/4.0/), which permits distribution, and reproduction in any medium, provided that the original author(s) and the source are credited.

Positions and opinions advanced in this work are those of the author(s) and not necessarily those of SAE International. Responsibility for the content of the work lies solely with the author(s).

ISSN 0148-7191 